\title{
Safety of Potato Consumption in Slovak Region Contaminated by Heavy Metals due to Previous Mining Activity
}

\author{
Janette Musilova, ${ }^{1}$ Judita Bystricka, ${ }^{1}$ Alena Vollmannova, ${ }^{1}$ Beata Janotova, ${ }^{1}$ Matyas Orsak, \\ Lubos Harangozo, ${ }^{1}$ and Alzbeta Hegedusova ${ }^{3}$ \\ ${ }^{1}$ Department of Chemistry, Faculty of Biotechnology and Food Sciences, Slovak University of Agriculture in Nitra, Nitra, Slovakia \\ ${ }^{2}$ Department of Chemistry, Faculty of Agrobiology, Food and Natural Resources, Czech University of Life Sciences Prague, Prague, \\ Czech Republic \\ ${ }^{3}$ Department of Vegetable Production, Faculty of Horticulture and Landscape Engineering, Slovak University of Agriculture in Nitra, \\ Nitra, Slovakia
}

Correspondence should be addressed to Janette Musilova; janette.musilova@uniag.sk

Received 18 July 2016; Revised 20 September 2016; Accepted 26 October 2016; Published 12 January 2017

Academic Editor: Jordi Rovira

Copyright (C) 2016 Janette Musilova et al. This is an open access article distributed under the Creative Commons Attribution License, which permits unrestricted use, distribution, and reproduction in any medium, provided the original work is properly cited.

\begin{abstract}
Heavy metals are among the most serious environmental contaminants in mining districts. Soil, as one of the main components of the environment, is the place of heavy metal entry into plants and consequently into the food chain, too. Potatoes grown in the region of Middle Spis (Slovakia) may be a source of increased content of heavy metals and pose a health risk to the consumer. The contents of heavy metals $(\mathrm{Cd}, \mathrm{Pb}$, and $\mathrm{Ni}$ ) in potato and soil samples were determined using the AAS method and compared with limit values set by the Slovak Republic and the European Union. The content of heavy metals was determined in 12 potato cultivars with different length of vegetation period (mid-early, very early, and early, resp.), which were grown in three localities with a highly disturbed environment. Total contents and mobile forms of heavy metals as well as physical and chemical properties were determined in soil samples which were collected from the same sampling sites. Only $\mathrm{Pb}$ content in potato tubers was higher than the hygienic limit value $\left(0.1 \mathrm{mg} \mathrm{kg}^{-1} \mathrm{FM}\right)$ in 15 sampling sites (interval was n.d. $\left.-0.2298 \mathrm{mg} \mathrm{kg}^{-1} \mathrm{FM}\right)$. The contents of exchangeable forms (total content) of heavy metals in soil were ranged between the intervals: Cd 0.004-0.055 (0.94-1 56), Pb 0.023-0.295 (17.0026.80), and Ni 0.019-0.475 (30.80-71.00) $\mathrm{mg} \mathrm{kg}^{-1}$. At current average consumption levels of potatoes, tolerable weekly intake (TWI) or tolerable daily intake (TDI) for observed heavy metals was not exceeded.
\end{abstract}

\section{Introduction}

Heavy metals contribute significantly to a reduction in environmental quality. Heavy metals can originate from both natural and anthropogenic sources [1]. When occurring naturally in the soil environment as a consequence of the pedogenetic processes of weathering of parent materials, their contents are at levels that are considered to be trace $(<1000 \mathrm{mg} / \mathrm{kg})$ [2]. Hazardous levels of heavy metals are usually associated with anthropogenic sources.

There are different sources of heavy metals in the environment. Other than natural sources there are agricultural sources (fertilizer use, sewage sludge application, and metalcontaining pesticides); industrial sources (petrochemicals); domestic effluents; atmospheric sources; and other sources (disposal of high metal waste in improperly protected landfill, leaded gasoline and lead-based paints, and coal combustion residues) [1-4].

Heavy metals are very persistent in the environment; they are not bio- and thermodegradable and are highly toxic and bioaccumulative $[5,6]$.

Heavy metals represent a potential human health hazard if safe thresholds of exposure or absorption are exceeded. Nonessential chemical elements $(\mathrm{Cd}, \mathrm{Pb}, \mathrm{Hg}$, etc.) are toxic even at relatively low concentrations, but also biologically irreplaceable microelements (e.g. $\mathrm{Cu}, \mathrm{Zn}, \mathrm{Mn}, \mathrm{Co}, \mathrm{Cr}$, etc.) would be toxic if a certain concentration level is exceeded [79]. 
The contamination of soil by cadmium is caused not only by industrial sources. One of important $\mathrm{Cd}$ sources could be also sewage sludge, which can be applied on soil as a fertilizer or as a treatment for improving soil structure [10]. Accumulation of $\mathrm{Cd}$ in the soil can be enhanced by the application of phosphate fertilizers, which are an important source of trace element enrichment in soils [11]. Nickel is present in natural soils at trace level concentration. However, its concentration is increasing in certain areas by human activities such as mining smelter emission, burning of coal and oil, sewage, phosphate fertilizers, and pesticides [1]. Accumulation of heavy metals such as lead and nickel in soil may impact soil properties, reduce soil biological activity, and hinder the effective supply of nutrients [12].

Cadmium $(\mathrm{Cd})$ is a highly toxic metal with a natural occurrence in soil, but it is also spread in the environment due to human activities [9] and can eventually enter the human body through the food chain [13]. The primary route for Cd exposure in humans is through ingestion of foods [14]. Cadmium is present virtually in all food, but the concentrations vary to a great extent, depending on the type of food and the $\mathrm{Cd}$ load in the food production environment [15]. The highest concentrations are present in seafood, molluscs and crustaceans, offal products, and certain seeds. Among plant foods, the highest concentrations are generally present in cereals such as wheat (especially whole grain) and rice, leafy green vegetables, and potatoes and root vegetables $[16,17]$.

Cadmium, which may accumulate in the human body, has an adverse effect on human health and may cause proteinuria, result in low bone mineral density, cause osteoporosis, and increase the risk of bone fracture. Cd also affects the female reproductive system and severely affects the female endocrine system. Chronic Cd dust or aerosols cause lung cancer, hypertension, and renal dysfunction [13, 18-22].

Lead $(\mathrm{Pb})$ is a highly toxic element, is bioaccumulative, and neither degrade in the environment nor is easily metabolized. It is another widespread toxic pollutant which has no known function in biological systems. The main anthropogenic sources of $\mathrm{Pb}$ that remain, such as mining, smelting, lead batteries, crystal, and ceramic industry, undoubtedly contribute to $\mathrm{Pb}$-induced adverse effects in humans and the environment [23]. Excessive intake of $\mathrm{Pb}$ can damage the central nervous system, skeletal, circulatory, enzymatic, endocrine, and immune systems, and kidneys in adults and cause delays in physical and mental development in children. It has been shown that $\mathrm{Pb}$ can disturb haemoglobin synthesis. After absorption, $\mathrm{Pb}$ enters the blood and then accumulates in erythrocytes and is bound to proteins or complexed with low molecular weight sulfhydryl compounds (e.g., cysteine, homocysteine). Organic lead can be more toxic than inorganic lead because the body absorbs it more readily. Potential exposures to organic lead should be taken very seriously $[6,13,18,21,23-25]$. Symptoms such as personality changes, irritability, persistent headache, abdominal colic, or treatment of neuropathy warrant parenteral chelation indicative of recent exposure to lead [26]. Peralta-Videa et al. [18] reported that in humans there is a correlation between $\mathrm{Pb}$ exposure and hearing loss.
Nickel $(\mathrm{Ni})$ is present in all soils, where it derives from either the parent material (lithosphere) or anthropogenic deposition or both [27]. Nickel is recognized as an essential micronutrient for living organisms and is a component of the enzyme urease [1]. While in small quantities nickel is necessary, deficiency causes growth retardation and anaemia and reduces the activity of certain enzymes [28, 29]. Its toxicity at higher levels is more prominent [9]. Large quantities of nickel may cause various consequences on human bodies, such as inflammation, cancer, neurasthenia, system disorders, lower fertility, and teratogenic, mutagenic, and heart disorders [28, 30]. Absorbed nickel is distributed in the body by the blood. In human serum nickel binds predominantly to albumin but also to 1-histidine and alpha-2-macroglobulin [31]. The main excretion route of absorbed nickel is via urine, independent of the route of exposure; small amounts of absorbed nickel are excreted in bile, sweat, hair, saliva, and mother's milk. People working in the nickel production and processing industry are exposed to a higher concentration of nickel. Their main route of exposure is inhalation and, to a lesser extent, contact with the skin [32]. Inhaled $\mathrm{Ni}$ compounds are carcinogenic to humans although there is a lack of evidence of a carcinogenic risk of Ni from oral exposure to humans [25].

Middle Spis is one of the at-risk regions of Slovakia with soils affected by acid pollutants as well as by heavy metals. Industrial enterprises in the localities Rudnany, Krompachy, and Spisska Nova Ves were the determining sources of environmental contamination for several decades. Despite a reduction in mining activities, the negative consequences of the metallurgical production in acid soils of this region still persist [33].

The aim of our study was to assess the quality of potatoes in terms of heavy metal content $(\mathrm{Ni}, \mathrm{Cd}$, and $\mathrm{Pb})$ in their edible parts. Potatoes were grown in three localities of Middle Spis, one of the most loaded regions of Slovakia with a disturbed environment due to previous intense mining activity.

\section{Material and Methods}

The potatoes for analyses were grown in three areas of the Middle Spis of Slovakia. Twelve potato cultivars with a different vegetation period were analysed: six cultivars (Arlet, Malvina, Megan, Spinela, Svella, and Timea) from the locality of Matejovce, three cultivars (Laura, Marabel, and Red Anna) from the locality of Odorin, and four cultivars (Laura, Smart, Victoria, and Vivaldi) from the locality of Spissky Stvrtok.

\section{Cultivars (Maturity, Shape of Tubers, Colour Skin/Colour Flesh)}

(i) Vivaldi: very early, oval, yellow/light yellow

(ii) Malvina and Svella: early, oval, yellow/yellow

(iii) Arlet, Marabel, Megan, and Victoria: mid-early, oval, yellow/yellow

(iv) Laura: mid-early, oval, red/deep yellow

(v) Red Anna: mid-early, short-oval, red/deep yellow 
(vi) Smart: mid-early, short-oval, yellow/deep yellow

(vii) Spinela: mid-early, oval, red/deep yellow

(viii) Timea: mid-early, short-oval, yellow/yellow

In all localities the standard technologies of potato cultivation were used.

In the autumn, $30 \mathrm{t} /$ ha of farmyard manure was applied and ploughed into the soil. Immediately before planting, $335 \mathrm{~kg}$ of Patenkali $\left(30 \% \mathrm{~K}_{2} \mathrm{O}, 10 \% \mathrm{MgO}\right.$, and $\left.42.5 \% \mathrm{SO}_{3}\right)$ was applied over the whole surface. During planting, $300 \mathrm{~kg}$ NPK $(15: 15: 15)$ was applied directly under the planted tubers, and the potato tubers were treated with a preparation Maxim $\left(0.1 \mathrm{~L} \mathrm{ha}^{-1}\right)$ which protects tubers against Rhizoctonia solani. After planting, the area was sprayed against weeds. During vegetation, the potato crops were protected against late potato blight and some viral diseases. Vegetation of the plants was finished by mechanical crushing of leaves and subsequent application of the preparation Reglone. All preparations have been applied according to manufacturer's recommendations. The tubers were harvested after the maturation of potato peels about 25 days after the application of Reglone.

Samples from each cultivar were collected in four repetitions at an amount of about $2 \mathrm{~kg}$ from each sample site. Soil samples were also taken at horizon $0-0.2 \mathrm{~m}$, using a pedological probe (GeoSampler fy. Fisher).

2.1. Soil Samples. Soil samples were air dried and disaggregated. Two fractions, fine earth $I$ (average $2 \mathrm{~mm}$ particle size) and fine earth II (average $0.125 \mathrm{~mm}$ particle size), were prepared for the determination for physical, chemical, and nutrient contents and for $\mathrm{Ni}, \mathrm{Cd}$, and $\mathrm{Pb}$ determination, respectively.

In soil samples the exchange soil reaction $(\mathrm{pH} / \mathrm{KCl})(\mathrm{i})$ and content of oxidizable carbon $\left(\mathrm{C}_{\mathrm{OX}}, \%\right)$ using volumetric method (ii) were determined. The content of Soil Organic Matter (SOM, \%) was calculated from value of $\mathrm{C}_{\mathrm{OX}}$ content.

\section{Chemicals and Equipment}

(i) KCl: CentralChem, Slovakia; $691 \mathrm{pH}$ Meter Metrohm, Swiss; $c(\mathrm{KCl})=1 \mathrm{~mol} \mathrm{~L}^{-1}$

(ii) $\mathrm{H}_{2} \mathrm{SO}_{4}, \quad \mathrm{~K}_{2} \mathrm{Cr}_{2} \mathrm{O}_{7}$, and $\left(\mathrm{NH}_{4}\right)_{2} \mathrm{Fe}\left(\mathrm{SO}_{4}\right)_{2} \cdot 6 \mathrm{H}_{2} \mathrm{O}$ : Merck, Germany

Content of nutrients was determined according to Mehlich III (iii), content of $\mathrm{P}$ using spectrophotometric method (iv), and content of $\mathrm{K}, \mathrm{Ca}$, and $\mathrm{Mg}$ (iv) using AAS method (v).

\section{Chemicals and Equipment}

(iii) $\mathrm{NH}_{4} \mathrm{NO}_{3}, \quad \mathrm{NH}_{4} \mathrm{~F}, \quad$ EDTA, $\mathrm{HNO}_{3}, \mathrm{H}_{2} \mathrm{SO}_{4}$, $\left(\mathrm{NH}_{4}\right)_{2} \mathrm{MoO}_{4}, \mathrm{C}_{8} \mathrm{H}_{4} \mathrm{~K}_{2} \mathrm{O}_{12} \mathrm{Sb}_{2} \cdot 3 \mathrm{H}_{2} \mathrm{O}$, and ascorbic acid: Merck, Germany

(iv) Spectrophotometer UV-VIS 1800, Shimadzu; $\lambda=$ $666 \mathrm{~nm}$

(v) VARIAN AASpectr DUO 240FS/240Z/UltrAA equipped with a D2 lamp background correction system, using an air-acetylene flame, Varian Ltd., Mulgrave, Australia.
Content of two forms of dangerous metals $\mathrm{Ni}, \mathrm{Cd}$, and $\mathrm{Pb}$ was determined using AAS method. Content of exchangeable forms of $\mathrm{Ni}, \mathrm{Cd}$, and $\mathrm{Pb}$ was determined in soil extract by $\mathrm{NH}_{4} \mathrm{NO}_{3}$ (vi), total content of $\mathrm{Ni}, \mathrm{Cd}$, and $\mathrm{Pb}$, including all metal forms with exception of silicate forms, in soil extract by aqua regia (vii).

\section{Chemicals and Equipment}

(vi) $\mathrm{NH}_{4} \mathrm{NO}_{3}$ : Merck, Germany; $c=1 \mathrm{~mol} \mathrm{~L}^{-1}$

(vii) $\mathrm{HCl}$ : CentralChem, Slovakia; $\mathrm{HNO}_{3}$ : Merck, Germany

Mineralization of the soil samples was performed by microwave digestion (MARS X-press, CEM USA) in a mixture of nitric acid and hydrochloric acid in a molar ratio of $1: 3$. Parameters used in the digestion process were heating to $150^{\circ} \mathrm{C}$ for 15 minutes, keeping it constant for 10 minutes, increasing to $160^{\circ} \mathrm{C}$, again keeping it constant for 10 minutes, and cooling for 20 minutes. A blank sample was treated in the same way. The digested substances were subsequently filtered through a quantitative filter paper Filtrak 390 (Munktell, Germany) and filled with deionized water to a volume of $100 \mathrm{~mL}$ [34].

The contents of $\mathrm{Ni}, \mathrm{Cd}$, and $\mathrm{Pb}$ in soil were determined using F-AAS method and GF-AAS method, respectively. Concentrations of $\mathrm{Ni}, \mathrm{Cd}$, and $\mathrm{Pb}$ were assessed at wavelengths of $232.0,228.8$, and $217.0 \mathrm{~nm}$, respectively. The respective limits of detection (LOD) for $\mathrm{Cd}, \mathrm{Pb}$, and $\mathrm{Ni}$ were $0.4,0.05$, and $1.0 \mathrm{mg} \mathrm{kg}^{-1}$; and their respective limits of quantification (LOQ) were $1.2,0.15$, and 3.0 and $\mathrm{mg} \mathrm{kg}^{-1}$.

The contents of $\mathrm{Ni}, \mathrm{Cd}$, and $\mathrm{Pb}$ were compared with limit and critical values according to Act number 220/2004.

2.2. Plant Samples. Potato tubers were collected in full maturity from investigated localities. The weight of each average sample was $2 \mathrm{~kg}$. After washing, peeling, and chopping approximately $150 \mathrm{~g}$ of sample was homogenized. About $30 \mathrm{~g}$ from homogenized sample was used for determination of dry matter and the rest of each sample was lyophilized and used for further analysis.

The contents of $\mathrm{Ni}, \mathrm{Cd}$, and $\mathrm{Pb}$ were determined in potatoes in extracts of freeze-dried samples. The samples were pulverized (i) and, afterwards, stored in precleaned polyethylene bottles until subsequent preanalytical operations.

Closed system of microwave digestion (ii) without using hydrogen peroxide was used for the mineralization of homogenized potato samples $\left(1.000 \mathrm{~g}\right.$ in a mixture of $5 \mathrm{~mL} \mathrm{HNO}_{3}$ and $5 \mathrm{~mL}$ deionized water (iii)). Digestion process steps comprised heating to $160^{\circ} \mathrm{C}$ for 15 minutes and keeping it constant for 10 minutes. The same way was used for blank sample preparation. After filtration (Filtrak 390; Munktell, Germany) of digested substances deionized water was added to a volume of $50 \mathrm{~mL}[34,35]$. The contents of heavy metals were determined using AAS (atomic absorption spectrometry) method: Cd, Pb: GF-AAS, and Ni F-AAS. The measured results were compared with the multielemental standard for GF-AAS (iv) and subsequently expressed in $\mathrm{mg} \mathrm{kg}^{-1}$ of 
TABLE 1: Basic agrochemical indicators and contents of nutrients.

\begin{tabular}{lcccccccc}
\hline Locality & & $\mathrm{pH} / \mathrm{KCl}$ & $\begin{array}{c}\text { Humus } \\
(\%)\end{array}$ & $\mathrm{N}$ & $\mathrm{P}$ & $\mathrm{K}$ & $\mathrm{Ca}$ \\
& & & & & \multicolumn{2}{c}{$\mathrm{Mg} / \mathrm{kg})$} \\
\hline \multirow{3}{*}{ Odorin } & Min. & 4.45 & 2.12 & 1400.0 & 32.52 & 132.50 & 1032.00 & 102.00 \\
& Max. & 5.42 & 3.33 & 2625.0 & 108.41 & 280.50 & 1880.00 & 188.00 \\
& Average & 5.15 & 2.65 & 1954.2 & 79.22 & 188.96 & 1443.83 & 134.83 \\
& STDEV & 0.23 & 0.33 & 386.5 & 19.84 & 46.29 & 274.81 & 26.54 \\
\hline \multirow{3}{*}{ Matejovce } & Min. & 4.95 & 2.00 & 2450.0 & 10.82 & 143.50 & 2008.00 & 124.00 \\
& Max. & 6.63 & 3.63 & 4900.0 & 62.42 & 268.00 & 3408.00 & 292.00 \\
& Average & 5.64 & 2.65 & 3441.7 & 35.59 & 186.23 & 2613.92 & 184.83 \\
Spissky & STDEV & 0.44 & 0.49 & 728.6 & 12.98 & 36.05 & 438.32 & 46.98 \\
Stvrtok & Min. & 4.69 & 2.36 & 1400.0 & 15.66 & 111.50 & 1146.00 & 114.00 \\
& Max. & 6.61 & 3.57 & 3150.0 & 98.69 & 256.50 & 3126.00 & 220.00 \\
& Average & 5.39 & 2.85 & 2395.3 & 42.69 & 190.31 & 1764.75 & 167.50 \\
& STDEV & 0.60 & 0.31 & 556.0 & 21.84 & 44.53 & 573.13 & 29.47 \\
\hline
\end{tabular}

fresh matter (FM). The water content of the samples was determined by the moisture analyser (v).

\section{Chemicals and Equipment}

(i) Grindomix 200 GD (Retsch, Germany)

(ii) Mars X-Press 5 (CEM Corp., USA)

(iii) $\mathrm{HNO}_{3}$ : Suprapur, Merck, Germany; deionized water: $0.054 \mathrm{mS} \mathrm{cm}^{-1}$ from Simplicity185 (Millipore, UK)

(iv) CertiPUR ${ }^{\circledR}$ : Merck, Germany

(v) DLB 160-3A: Kern, Germany

Contents of heavy metals determined in plant samples were evaluated according to maximum allowed amounts given by the Foodstuffs Codex of the Slovak Republic and EC number 1881/2006.

2.3. Statistical Analysis. Results were statistically evaluated by Analysis of Variance (ANOVA, Multiple Range Tests, Method: 95.0 percent LSD) using statistical software Statgraphics (Centurion XVI.I, USA) and a regression and correlation analysis (Microsoft Excel) was used.

\section{Results and Discussion}

3.1. Soil. The results of chemical analysis focused on agrochemical characteristics (values of exchangeable soil reaction, content of humus, oxidizable carbon, and contents of available nutrients: $\mathrm{P}, \mathrm{K}, \mathrm{Ca}, \mathrm{Mg}$ ) are presented in Table 1 .

The average soil $\mathrm{P}$ amount in all sampling sites was lower than satisfactory content for potato cultivation (100$125 \mathrm{mg} \mathrm{P}$ per kilogram of soil), contents of $\mathrm{K}$ and $\mathrm{Mg}$ were satisfactory (recommended values are $140-220 \mathrm{mg} \mathrm{K} \mathrm{kg}^{-1}$ and $110-180 \mathrm{mg} \mathrm{Mg} \mathrm{kg}^{-1}$ ), and average values of soil reaction were lower compared to recommended $\mathrm{pH}$ values ( $\mathrm{pH}$ 5.56.5), although according to Vokal et al. [36] there is no decrease of tuber yield at lower $\mathrm{pH}$ values around $\mathrm{pH}$ 4.8 .

Optimal Soil Organic Matter (SOM) content for potato cultivation should be higher than $2 \%$; this value was exceeded at all sampling sites. Based on these characteristics all three localities can be considered suitable for potato cultivation with a requirement of $\mathrm{P}$ enrichment through fertilization. All surveyed localities are a part of the Spis region which was known for potato cultivation in the past.

The determination of $\mathrm{Cd}, \mathrm{Pb}$, and $\mathrm{Ni}$ content served as hygienic criterion for assessment of soil suitability for potato cultivation. Heavy metal contents in soil (Table 2), determined using GF-AAS and Ni F-AAS methods, were compared to limit values (for a soil extract by aqua regia) and critical values (for a soil extract by $\mathrm{NH}_{4} \mathrm{NO}_{3}$ ) according to legislation valid in the Slovak Republic (Act number 220/2004).

Determined total contents of heavy metals were in the range of $0.94-1.56(\mathrm{Cd}), 17.00-26.80(\mathrm{~Pb})$, and 30.80-71.00 (Ni) $\mathrm{mg} \mathrm{kg}^{-1}$, respectively.

Values for the Cd limit $\left(0.7 \mathrm{mg} \mathrm{kg}^{-1}\right)$ were exceeded in all sampling sites (SS), while the determined total $\mathrm{Pb}$ content in soil was below the limit value $\left(<70 \mathrm{mg} \mathrm{kg}^{-1}\right)$. The determined total $\mathrm{Ni}$ content $\left(>50 \mathrm{mg} \mathrm{kg}^{-1}\right)$ in soil was exceeded in $14 \mathrm{SS}$ (12 SS locality Matejovce, 2 SS locality Spissky Stvrtok).

The total contents of heavy metals include all metal forms with the exception of their residual fractions. Their high content determined in a soil extract by aqua regia may be not reflected by high heavy metal content in the harvested crop. Bioavailability of heavy metals by plants can be affected by changes in soil properties. In general, the mobility of heavy metals is associated with soil reaction, cation exchange capacity, soil organic content, and soil texture and is increased with decrease in soil $\mathrm{pH}$ value. Due to the increased availability of heavy metals by plants, their input into the human body via the food chain could ultimately be increased [3742]. Besides soil pH, organic matter content in soil is also 
TABLE 2: Contents of heavy metals in soil determined in different soil extracts.

\begin{tabular}{|c|c|c|c|c|c|c|c|}
\hline \multirow[b]{2}{*}{ Locality } & & \multicolumn{3}{|c|}{ aqua regia } & \multicolumn{3}{|c|}{$\mathrm{NH}_{4} \mathrm{NO}_{3}$} \\
\hline & & $\mathrm{Cd}$ & $\begin{array}{c}\mathrm{Pb} \\
(\mathrm{mg} / \mathrm{kg})\end{array}$ & $\mathrm{Ni}$ & $\mathrm{Cd}$ & $\begin{array}{c}\mathrm{Pb} \\
(\mathrm{mg} / \mathrm{kg})\end{array}$ & $\mathrm{Ni}$ \\
\hline \multirow{4}{*}{ Odorin } & Min. & 0.94 & 17.00 & 30.80 & 0.026 & 0.080 & 0.140 \\
\hline & Max. & 1.35 & 24.40 & 50.00 & 0.047 & 0.205 & 0.395 \\
\hline & Average & 1.19 & 19.88 & 39.53 & 0.033 & 0.148 & 0.223 \\
\hline & STDEV & 0.13 & 1.66 & 4.33 & 0.006 & 0.032 & 0.059 \\
\hline \multirow{4}{*}{ Matejovce } & Min. & 1.16 & 17.40 & 33.00 & 0.004 & 0.023 & 0.019 \\
\hline & Max. & 1.56 & 25.40 & 71.00 & 0.055 & 0.295 & 0.380 \\
\hline & Average & 1.34 & 21.84 & 52.59 & 0.045 & 0.227 & 0.228 \\
\hline & STDEV & 0.12 & 1.69 & 9.01 & 0.012 & 0.035 & 0.066 \\
\hline \multirow{4}{*}{$\begin{array}{l}\text { Spissky } \\
\text { Stvrtok }\end{array}$} & Min. & 1.00 & 17.60 & 37.40 & 0.023 & 0.090 & 0.105 \\
\hline & Max. & 1.44 & 26.80 & 51.20 & 0.047 & 0.210 & 0.475 \\
\hline & Average & 1.21 & 20.44 & 45.95 & 0.034 & 0.149 & 0.241 \\
\hline & STDEV & 0.12 & 2.17 & 3.37 & 0.007 & 0.030 & 0.072 \\
\hline Limit value & & 0.4 & 70.0 & 50.0 & & & \\
\hline Critical value & & & & & 0.1 & 0.1 & 1.5 \\
\hline
\end{tabular}

one of the most important soil properties affecting heavy metal availability. Organic matter is a major contributor to the ability of soils to retain heavy metals in an exchangeable form $[38,43]$. Adsorption of heavy metals is also highly dependent on soil components that include silicate clays, organic matter, iron, aluminium, and manganese oxides [44, 45].

The soil contents of $\mathrm{Cd}, \mathrm{Pb}$, and $\mathrm{Ni}$ are variable (e.g., northern Pakistan, southwestern China, Wallonia region of Belgium, and northwest of Iran: $\mathrm{Cd}$ 0.08-4.5, $\mathrm{Pb}$ 17.0-672.0, and Ni $0.46-103.0 \mathrm{mg} \mathrm{kg}^{-1}$ soil) depending on agroclimatic conditions $[27,46-48]$.

Heavy metals in soils may be present in several forms with different levels of solubility: (1) being dissolved (in soil solution); (2) exchangeable organic and inorganic components; (3) structural components of the lattices in soils; and (4) being insolubly precipitated with other soil components. Usually, only the first two forms are able to be absorbed and utilized by plants [38]. In our case, mobile forms of heavy metals could be hazardous. The contents of exchangeable $\mathrm{Cd}$, $\mathrm{Pb}$, and $\mathrm{Ni}$ forms determined in soil extract by $\mathrm{NH}_{4} \mathrm{NO}_{3}$ were in intervals $0.004-0.055\left(0.023-0.295,0.019-0.475 \mathrm{mg} \mathrm{kg}^{-1}\right.$, resp.). Critical value given for $\mathrm{Pb}\left(0.1 \mathrm{mg} \mathrm{kg}^{-1}\right)$ was exceeded in $35 \mathrm{SS}$. Lead $(\mathrm{Pb})$ is one of the most ubiquitously distributed abundant toxic elements in the soil. It exerts an adverse effect on the morphology, growth, and photosynthetic processes of plants [1]. Lead has the strongest chemical bond by specific adsorption processes of the all heavy metals and is immobilized in soil when it forms complexes with organic matter [18, 49]. As a result of acid soil reaction (in some cases, strong acid soil reaction, Table 1), its availability can be increased. Contents of mobile $\mathrm{Ni}$ and $\mathrm{Cd}$ forms were lower than critical values $\left(\mathrm{Ni}<1.5 \mathrm{mg} \mathrm{kg}^{-1}, \mathrm{Cd}<0.1 \mathrm{mg} \mathrm{kg}^{-1}\right)$. No correlation between total contents of metals and their exchangeable forms could be explained by the fact that the part of $\mathrm{Cd}$ and $\mathrm{Ni}$ is irreversibly bound on $\mathrm{Fe}$ and $\mathrm{Mn}$ oxides as well as clay minerals. Nickel is partly bound also with silicates [50].

3.2. Plant. Increased levels of heavy metals in soil are reflected in increased metal concentration in potatoes only to limited extent (Table 3 ).

Content of Cd determined in potato tubers was not higher than $0.1 \mathrm{mg} \mathrm{kg}^{-1} \mathrm{FM}$. This value is given by the Foodstuffs Codex of the Slovak Republic as well as Commision Regulation (EC) number 1881/2006 as the maximum allowed amount of $\mathrm{Cd}$ in potatoes. The lowest $\mathrm{Cd}$ content (below the detection limit) was found in the potatoes of cultivar Timea (locality Matejovce) and the highest one (average Cd content: $0.057 \pm 0.005 \mathrm{mg} \mathrm{kg}^{-1} \mathrm{FM}$ ) in cultivar Victoria (locality Spissky Stvrtok, max. Cd content: $0.065 \mathrm{mg} \mathrm{kg}^{-1}$ FM). A strong correlation between content of exchangeable $\mathrm{Cd}$ forms in soil and $\mathrm{Cd}$ content in potato tubers was only confirmed in the locality of Spissky Stvrtok $(R=$ $0.823, P$ value $=7.881 E-07)($ Figure $1(\mathrm{a}))$. In localities Odorin (Figure 1(b)) and Matejovce (Figure 1(c)) only weak correlation between exchangeable $\mathrm{Cd}$ forms in soil and $\mathrm{Cd}$ content in potato tubers was confirmed.

Of the observed heavy metals, lead seems to be the most hazardous one from the aspect of plant contamination. The high content of $\mathrm{Pb}$ mobile forms (the determined $\mathrm{Pb}$ content higher than limit value: $89.7 \%$ of all investigated soil samples) was reflected in enhanced $\mathrm{Pb}$ content in potato tubers. In $19.2 \%$ of potato samples the $\mathrm{Pb}$ content was higher than the maximum level for potatoes $\left(0.1 \mathrm{mg} \mathrm{Pb} \mathrm{kg}^{-1} \mathrm{FM}\right)$. In samples from 3 sampling sites ( 2 SS cultivar Svella, locality Matejovce, and 1 SS cultivar Laura, locality Odorin) the determined $\mathrm{Pb}$ content was below the detection limit; the 
TABLE 3: Contents of heavy metals in potato tubers.

\begin{tabular}{|c|c|c|c|c|}
\hline Locality & Cultivar & $\mathrm{Cd}$ & $\begin{array}{c}\mathrm{Pb} \\
(\mathrm{mg} / \mathrm{kg} \mathrm{FM})\end{array}$ & $\mathrm{Ni}$ \\
\hline \multirow{3}{*}{ Odorin } & Laura & $0.030 \pm 0.001^{b}$ & $0.074 \pm 0.062^{\mathrm{a}}$ & $0.326 \pm 0.132^{\mathrm{a}}$ \\
\hline & Marabel & $0.024 \pm 0.002^{\mathrm{a}}$ & $0.116 \pm 0.064^{\mathrm{a}}$ & $0.249 \pm 0.091^{b}$ \\
\hline & Red Anna & $0.031 \pm 0.001^{c}$ & $0.058 \pm 0.023^{\mathrm{a}}$ & $0.112 \pm 0.027^{b}$ \\
\hline \multirow{4}{*}{ All cultivars } & Min. & 0.022 & n.d. & 0.078 \\
\hline & Max. & 0.033 & 0.230 & 0.530 \\
\hline & Average & 0.028 & 0.083 & 0.229 \\
\hline & STDEV & 0.004 & 0.056 & 0.126 \\
\hline \multirow{6}{*}{ Matejovce } & Arlet & $0.014 \pm 0.002^{\mathrm{d}}$ & $0.048 \pm 0.005^{\mathrm{b}}$ & $0.108 \pm 0.019^{\mathrm{a}}$ \\
\hline & Malvina & $0.018 \pm 0.001^{\mathrm{e}}$ & $0.088 \pm 0.046^{\mathrm{c}}$ & $0.280 \pm 0.141^{\mathrm{c}}$ \\
\hline & Megan & $0.008 \pm 0.002^{c}$ & $0.060 \pm 0.025^{b c}$ & $0.175 \pm 0.092^{\mathrm{ab}}$ \\
\hline & Spinela & $0.021 \pm 0.001^{\mathrm{f}}$ & $0.062 \pm 0.033^{\mathrm{bc}}$ & $0.245 \pm 0.060^{b c}$ \\
\hline & Svella & $0.002 \pm 0.002^{\mathrm{b}}$ & $0.013 \pm 0.018^{\mathrm{a}}$ & $0.238 \pm 0.012^{b c}$ \\
\hline & Timea & n.d. ${ }^{\mathrm{a}}$ & $0.047 \pm 0.002^{\mathrm{b}}$ & $0.191 \pm 0.094^{\mathrm{abc}}$ \\
\hline \multirow{4}{*}{ All cultivars } & Min. & 0.000 & n.d. & 0.069 \\
\hline & Max. & 0.022 & 0.155 & 0.464 \\
\hline & Average & 0.011 & 0.053 & 0.206 \\
\hline & STDEV & 0.008 & 0.033 & 0.096 \\
\hline \multirow{4}{*}{ Spissky Stvrtok } & Laura & $0.036 \pm 0.002^{\mathrm{a}}$ & $0.103 \pm 0.036^{c}$ & $0.301 \pm 0.124^{\mathrm{ab}}$ \\
\hline & Smart & $0.041 \pm 0.002^{\mathrm{b}}$ & $0.058 \pm 0.019^{\mathrm{ab}}$ & $0.177 \pm 0.086^{\mathrm{a}}$ \\
\hline & Victoria & $0.057 \pm 0.005^{\mathrm{d}}$ & $0.079 \pm 0.026^{\mathrm{bd}}$ & $0.327 \pm 0.161^{b}$ \\
\hline & Vivaldi & $0.047 \pm 0.002^{c}$ & $0.032 \pm 0.011^{\mathrm{a}}$ & $0.168 \pm 0.027^{\mathrm{a}}$ \\
\hline \multirow{4}{*}{ All cultivars } & Min. & 0.033 & 0.024 & 0.086 \\
\hline & Max. & 0.065 & 0.163 & 0.589 \\
\hline & Average & 0.045 & 0.068 & 0.243 \\
\hline & STDEV & 0.009 & 0.036 & 0.127 \\
\hline \multicolumn{2}{|c|}{ EC No. 1881/2006 (FC SR) } & $0.1(0.1)$ & $0.1(0.1)$ & $-(0.5)$ \\
\hline
\end{tabular}

Notes: n.d.: not detected, a, b, c, and d: statistically significant differences between potato cultivars in the same locality, and $P$ value $<0.05$.

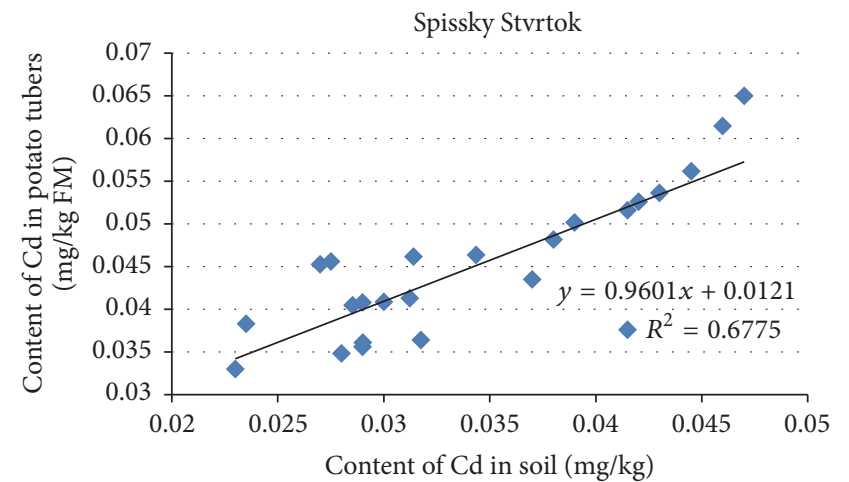

(a)

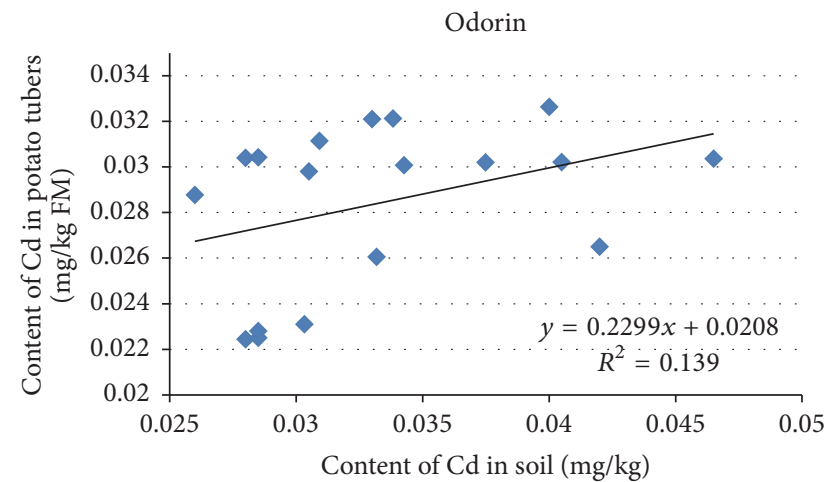

(b)

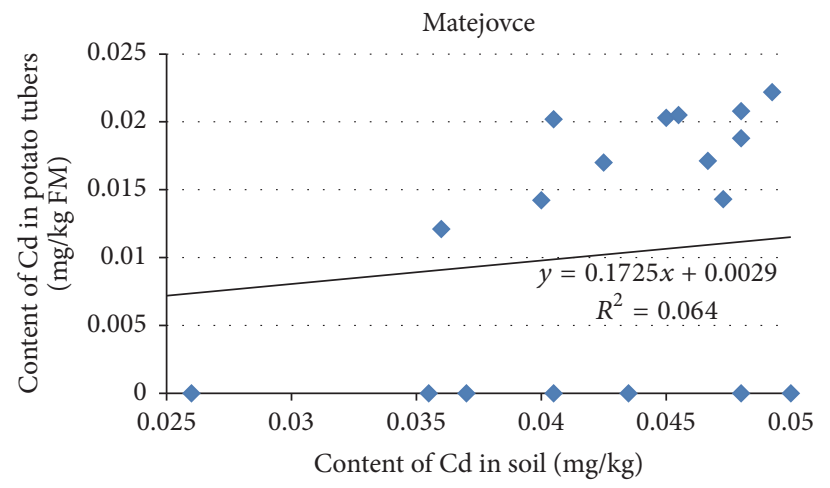

(c)

FIGURE 1: Content of Cd in potato tubers in relationship to content of cadmium (exchangeable forms) in soil: (a) locality Spissky Stvrtok; (b) locality Odorin; (c) locality Matejovce. 


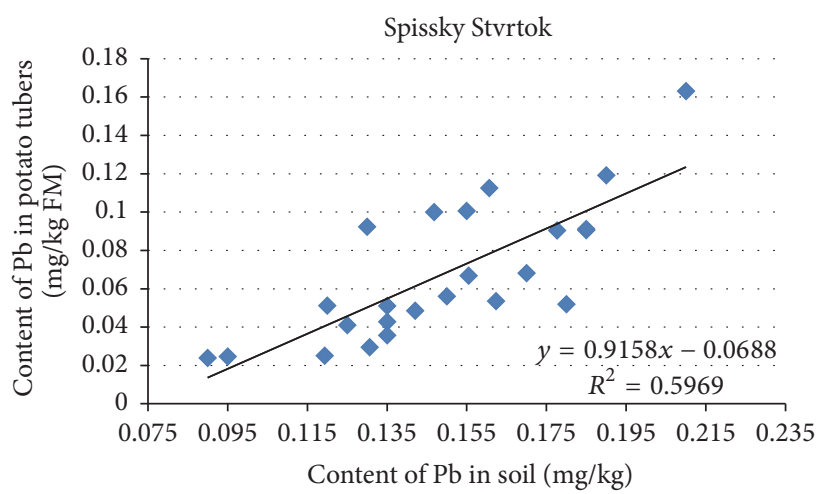

(a)

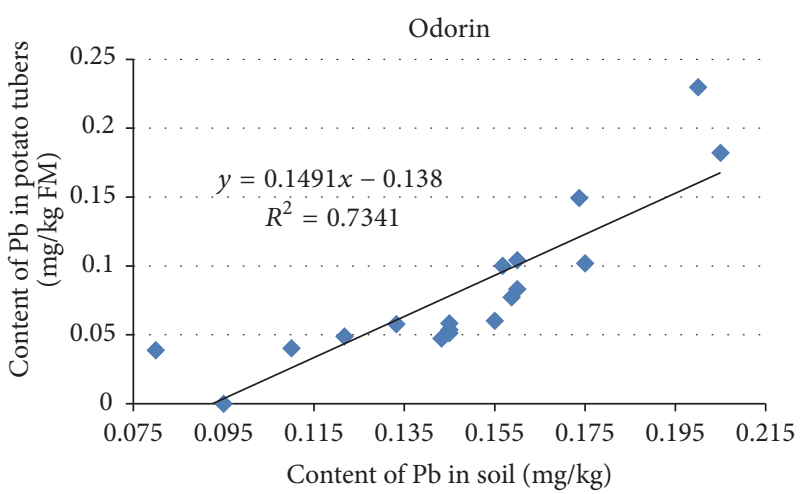

(b)

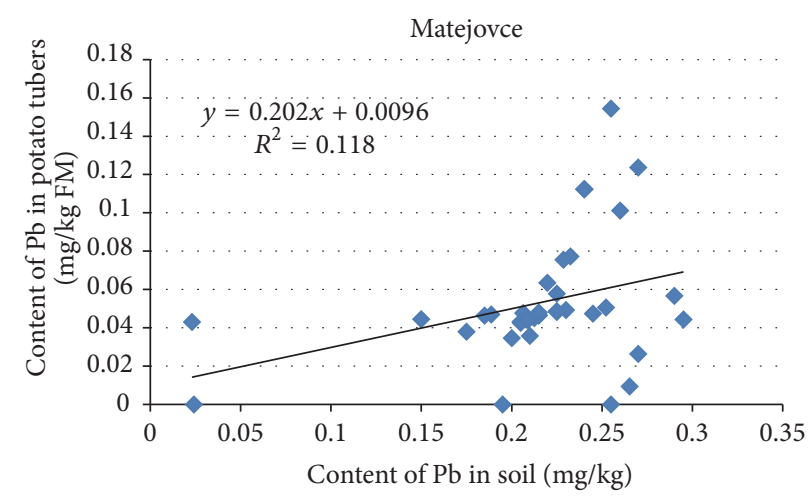

(c)

Figure 2: Content of $\mathrm{Pb}$ in potato tubers in relationship to content of lead (exchangeable forms) in soil: (a) locality Spissky Stvrtok; (b) locality Odorin; (c) locality Matejovce.

highest average $\mathrm{Pb}$ content $\left(0.117 \pm 0.064 \mathrm{mg} \mathrm{Pb} \mathrm{kg}^{-1} \mathrm{FM}\right)$ was in cultivar Marabel, locality Odorin (max. $\mathrm{Pb}$ content: $0.230 \mathrm{mg} \mathrm{kg}^{-1} \mathrm{FM}$ ). Medium-to-strong correlation between content of $\mathrm{Pb}$ mobile forms in soil and $\mathrm{Pb}$ content in potato tubers was confirmed (from $R=0.344$ (locality Matejovce) to $R=0.857$ (locality Odorin), Figures $2(\mathrm{a})-2(\mathrm{c})$ ).

For Ni content in foodstuffs there is not any limit value given by legislation in the EU. The determined $\mathrm{Ni}$ amount was compared to the limit value given FC SR $\left(0.5 \mathrm{mg} \mathrm{kg}^{-1}\right.$ FM). Only in 2 from all the investigated potato samples was the determined Ni content higher than $0.5 \mathrm{mg} \mathrm{kg}^{-1} \mathrm{FM}(0.530$ (cultivar Laura, locality Odorin) and 0.589 (cultivar Victoria, locality Spissky Stvrtok) $\mathrm{mg} \mathrm{Ni} \mathrm{kg}^{-1}$ resp.). Despite this fact, a medium-strong correlation between $\mathrm{Ni}$ content in soil and its content in potatoes was confirmed (from $R=0.531$ (locality Matejovce) to $R=0.729$ (locality Spissky Stvrtok), Figures 3(a)-3(c)).

Based on the statement on tolerable weekly intake for $\mathrm{Cd}$ and $\mathrm{Pb}$ and tolerable daily intake for $\mathrm{Ni}$ and considering the relatively low potato consumption in Slovakia $(47 \mathrm{~kg}$ per person/year) potatoes as the traditional food in this region are safe [51].

Potatoes (Solanum tuberosum) are one of the most important crops in the world (potato production in 2013: 376.453 mil. tons (http://potatopro.com/)). Their cultivation in
Slovakia has a long tradition; despite this fact, the potato consumption during the last twenty years gradually decreases. While in 1993 potato consumption was $89.0 \mathrm{~kg} / \mathrm{person} / \mathrm{year}$, in 2014 it was reduced by $48 \%$ ( $47.0 \mathrm{~kg} /$ person/year) [51]. At current consumption, the weekly intake of $\mathrm{Cd}(\mathrm{Pb}, \mathrm{Ni})$ due to the consumption of potatoes is with the highest content of these heavy metals ( $\mathrm{Cd} 0.065, \mathrm{~Pb}$ and $\mathrm{Ni} 0.230$ and $0.589 \mathrm{mg} \mathrm{kg}^{-1} \mathrm{FM}$, Table 3) lower compared to values of TWI for $\mathrm{Cd}$ and $\mathrm{Pb}$ and TDI for Ni given by EFSA (Tables 3 and 4).

Neither due to the consumption of potatoes in the amount of $84.9 \mathrm{~kg}$, which is the maximum allowed interval of rational potato consumption (76.3-84.9 kg per person/year), nor due to the recommended dose of potatoes $(80.6 \mathrm{~kg}$ per person/year) was the TWI or TDI for observed heavy metals exceeded (Table 4).

Heavy metal accumulation may also differ greatly within cultivars of an individual species when grown on the same soil [56]. This fact is also confirmed by our results (Table 3).

Results in this study correlate with results obtained in previous research. The $\mathrm{Cd}, \mathrm{Pb}$, and $\mathrm{Ni}$ contents in Slovakian potato cultivars were in the intervals $0.028-0.357$, n.d. -0.638 , and $0.194-0.220 \mathrm{mg} \mathrm{kg}^{-1} \mathrm{FM}$, respectively [57, 58]. Similar results were published also by other authors. Average values (mg kg${ }^{-1} \mathrm{FM}$ ) of $\mathrm{Cd}$ (n.d. -3870), Pb (0.005-4.65), and $\mathrm{Ni}$ 


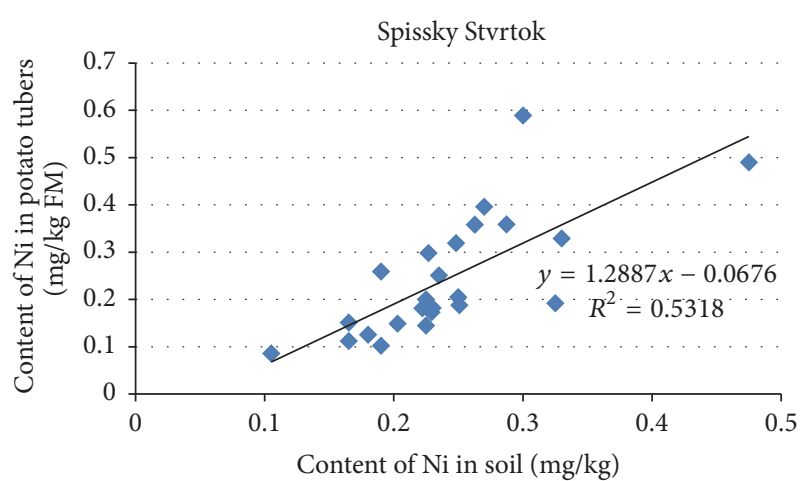

(a)

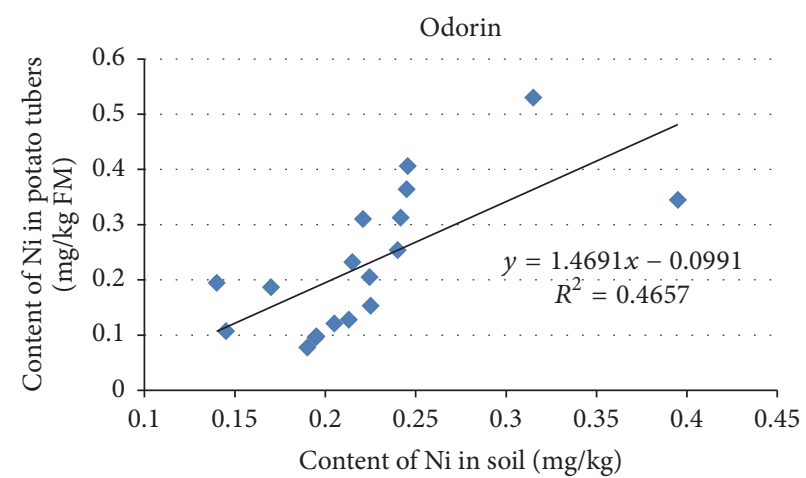

(b)

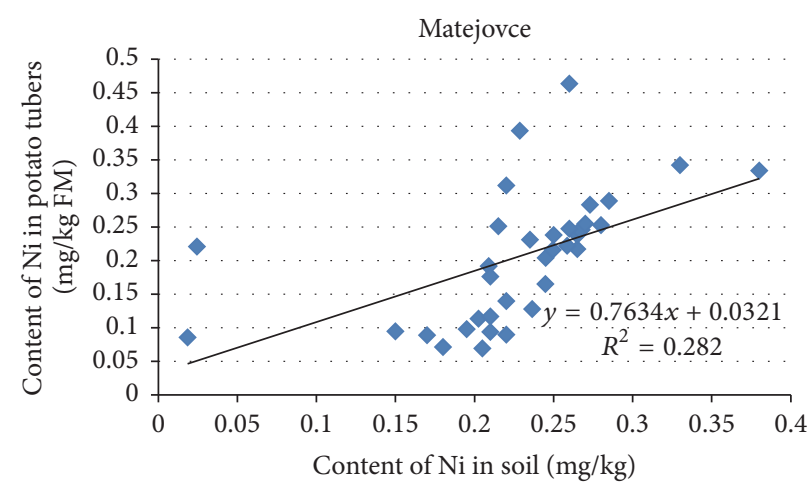

(c)

FIGURE 3: Content of $\mathrm{Ni}$ in potato tubers in relationship to content of nickel (exchangeable forms) in soil: (a) locality Spissky Stvrtok; (b) locality Odorin; (c) locality Matejovce.

TABLE 4: Calculated tolerable intake of heavy metals.

\begin{tabular}{lcccc}
\hline & $\begin{array}{c}\text { TWI, TDI } \\
(\text { g/kg b.w. })\end{array}$ & $\begin{array}{c}\text { TWI (70) } \\
(\text { mg/person })\end{array}$ & $\begin{array}{c}\text { MaxWI (47) } \\
(\text { mg/person) }\end{array}$ & $\begin{array}{c}\text { MaxWI (84.9) } \\
(\mathrm{mg} / \text { person) }\end{array}$ \\
\hline $\mathrm{Cd}$ & 2.5 & 0.175 & 0.059 & 0.106 \\
$\mathrm{~Pb}$ & 25.0 & 1.750 & 0.208 & 0.376 \\
$\mathrm{Ni}$ & $2.8^{*}$ & 1.372 & 0.532 & 0.962 \\
\hline
\end{tabular}

Notes: TWI: tolerable weekly intake [52, 53]; TDI: tolerable daily intake [54]; b.w.: body weight; MaxWI: maximum weekly intake, calculated according to the highest value of $\mathrm{Cd}(\mathrm{Pb}, \mathrm{Ni})$ content determined in potatoes in regard to consumption $47(84.9) \mathrm{kg}$ potatoes per year: $\mathrm{MaxWI}_{\mathrm{Cd}}=0.065 * 47 / 52\left(\mathrm{MaxWI} \mathrm{I}_{\mathrm{C}}=\right.$ $0.065 * 84.9 / 52), \mathrm{MaxWI}_{\mathrm{Pb}}=0.230 * 47 / 52\left(\mathrm{MaxWI}_{\mathrm{Pb}}=0.230 * 84.9 / 52\right), \mathrm{MaxWI}_{\mathrm{Ni}}=0.589 * 47 / 52\left(\mathrm{MaxWI}_{\mathrm{Ni}}=0.589 * 84.9 / 52\right),(70$, in kg $)-\operatorname{default}$ body weight used as default for the European adult population (aged above 18 years) [55]; (47, in kg/person/year): average consumption of potatoes [51]; (84.9, in $\mathrm{kg} /$ person/year): maximum in available interval of rational consumption of potatoes [51].

(n.d. -2.50) content were determined in potatoes conventionally and organically farmed in Egypt and in potatoes from Algeria, Australia, Bolivia, Brazil, China, Pakistan, Saudi Arabia, Ethiopia, and Iran [11, 24, 25, 27, 39, 46, 59-62].

\section{Conclusions}

In soil samples from all 3 investigated localities, the determined total Cd content was at least by $100 \%$ higher than the limit value. On the other hand the maximum content of exchangeable forms was significantly lower than the critical value. Similarly, the increased total content of Ni (max. 42\%) was not reflected in increased content of mobile forms. The contents of $\mathrm{Cd}$ and $\mathrm{Ni}$ in potatoes cultivated in observed localities are lower than allowed by hygiene standards. On the other hand the total $\mathrm{Pb}$ contents in soil were below the limit value, but the determined contents of mobile $\mathrm{Pb}$ forms exceeded the limit value in 16 SS by at least $100 \%$. Enhanced soil $\mathrm{Pb}$ contents were reflected in $\mathrm{Pb}$ accumulation in potatoes. The $\mathrm{Pb}$ content exceeded the limit value in almost $20 \%$ of analysed samples. The high content of mobile forms of $\mathrm{Pb}$ and also the high $\mathrm{Cd}$ total content may be reflected in their increased mobility and their ability to be accumulated in cultivated crops during change of soil conditions.

\section{Additional Points}

Practical Applications. Increased content of heavy metals in soil represents a potential risk of contamination for agricultural production. Therefore, not only the yield of tubers but 
also their quality including safety to human health is important for producers and consumers of potatoes. Increased levels of heavy metals in soil are reflected in increased metal concentration in potatoes only to a limited extent (determined $\mathrm{Pb}$ content higher than limit value: $89.7 \%$ of soil samples, $19.2 \%$ of potato samples). Our results confirmed correlations between $\mathrm{Ni}, \mathrm{Cd}$, and $\mathrm{Pb}$ contents in soil and potatoes. This fact indicates the risk of potato contamination by heavy metals when their soil contents, especially contents of mobile metals forms, are high. Based on the statement on TWI for $\mathrm{Cd}$ and $\mathrm{Pb}$ and TDI for $\mathrm{Ni}$ and considering the relatively low potato consumption in Slovakia, potatoes are safe.

\section{Competing Interests}

The authors declare that they have no competing interests.

\section{Acknowledgments}

This work was supported by Grant VEGA no. 1/0290/14 and VEGA no. 1/0308/14.

\section{References}

[1] P. C. Nagajyoti, K. D. Lee, and T. V. M. Sreekanth, "Heavy metals, occurrence and toxicity for plants: a review," Environmental Chemistry Letters, vol. 8, no. 3, pp. 199-216, 2010.

[2] R. A. Wuana and F. E. Okieimen, "Heavy metals in contaminated soils: a review of sources, chemistry, risks and best available strategies for remediation," ISRN Ecology, vol. 2011, Article ID 402647, 20 pages, 2011.

[3] D. Xu, Z. Chen, K. Sun, D. Yan, M. Kang, and Y. Zhao, "Effect of cadmium on the physiological parameters and the subcellular cadmium localization in the potato (Solanum tuberosum L.)," Ecotoxicology and Environmental Safety, vol. 97, pp. 147-153, 2013.

[4] Q. Zhao, Y. Wang, Y. Cao et al., "Potential health risks of heavy metals in cultivated topsoil and grain, including correlations with human primary liver, lung and gastric cancer, in Anhui province, Eastern China," Science of the Total Environment, vol. 470-471, pp. 340-347, 2014.

[5] S. Stasinos and I. Zabetakis, "The uptake of nickel and chromium from irrigation water by potatoes, carrots and onions," Ecotoxicology and Environmental Safety, vol. 91, pp. 122-128, 2013.

[6] G. Liu, Y. Yu, J. Hou et al., "An ecological risk assessment of heavy metal pollution of the agricultural ecosystem near a leadacid battery factory," Ecological Indicators, vol. 47, pp. 210-218, 2014.

[7] J. Tomas, T. Toth, and P. Lazor, "The state of soil hygiene in regions lowlands SR in terms of heavy metals in different extractant," Acta Fytotechnica et Zootechnica, vol. 3, pp. 16-20, 2000, [in Slovak].

[8] U. Çelik and J. Oehlenschläger, "High contents of cadmium, lead, zinc and copper in popular fishery products sold in Turkish supermarkets," Food Control, vol. 18, no. 3, pp. 258-261, 2007.

[9] F. Zhu, W. Fan, X. Wang, L. Qu, and S. Yao, "Health risk assessment of eight heavy metals in nine varieties of edible vegetable oils consumed in China," Food and Chemical Toxicology, vol. 49, no. 12, pp. 3081-3085, 2011.

[10] T. Toth, J. Tomas, P. Lazor, D. Bajcan, and L. Lahucky, "The impact of bio-sludge obtained by continuous co-fermentation of animal waste to the state of soil health and quality of grown crops," Chemické Listy, vol. 100, pp. 718-719, 2006, [in Slovak].

[11] A. P. B. Corguinha, V. C. Gonçalves, G. A. de Souza et al., "Cadmium in potato and soybeans: do phosphate fertilization and soil management systems play a role?" Journal of Food Composition and Analysis, vol. 27, no. 1, pp. 32-37, 2012.

[12] L.-M. Cai, J. Ma, Y.-Z. Zhou et al., "Multivariate geostatistics and GIS-based approach to study the spatial distribution and sources of heavy metals in agricultural soil in the Pearl River Delta, China," Environmental Science, vol. 29, no. 12, pp. 34963502, 2008.

[13] X. Chen, K. Wang, Z. Wang et al., "Effects of lead and cadmium co-exposure on bone mineral density in a Chinese population," Bone, vol. 63, pp. 76-80, 2014.

[14] A. L. Pérez and K. A. Anderson, "DGT estimates cadmium accumulation in wheat and potato from phosphate fertilizer applications," Science of the Total Environment, vol. 407, no. 18, pp. 5096-5103, 2009.

[15] L. Hellström, B. Persson, L. Brudin, K. Petersson Grawé, I. Öborn, and L. Järup, "Cadmium exposure pathways in a population living near a battery plant," Science of the Total Environment, vol. 373, no. 2-3, pp. 447-455, 2007.

[16] A. Engström, K. Michaëlsson, M. Vahter, B. Julin, A. Wolk, and A. Åkesson, "Associations between dietary cadmium exposure and bone mineral density and risk of osteoporosis and fractures among women," Bone, vol. 50, no. 6, pp. 1372-1378, 2012.

[17] Y.-R. Ju, W.-Y. Chen, and C.-M. Liao, "Assessing human exposure risk to cadmium through inhalation and seafood consumption," Journal of Hazardous Materials, vol. 227-228, pp. 353-361, 2012.

[18] J. R. Peralta-Videa, M. L. Lopez, M. Narayan, G. Saupe, and J. Gardea-Torresdey, "The biochemistry of environmental heavy metal uptake by plants: implications for the food chain," The International Journal of Biochemistry \& Cell Biology, vol. 41, no. 8-9, pp. 1665-1677, 2009.

[19] N. D. Minh, R. L. Hough, L. T. Thuy et al., "Assessing dietary exposure to cadmium in a metal recycling community in Vietnam: age and gender aspects," Science of the Total Environment, vol. 416, pp. 164-171, 2012.

[20] W.-L. Zhang, Y. Du, M.-M. Zhai, and Q. Shang, "Cadmium exposure and its health effects: a 19-year follow-up study of a polluted area in china," Science of the Total Environment, vol. 470-471, pp. 224-228, 2014.

[21] H. Chen, Y. Teng, S. Lu, Y. Wang, and J. Wang, "Contamination features and health risk of soil heavy metals in China," Science of the Total Environment, vol. 512-513, pp. 143-153, 2015.

[22] Q. L. Liao, C. Liu, H. Y. Wu et al., "Association of soil cadmium contamination with ceramic industry: a case study in a Chinese town," Science of the Total Environment, vol. 514, pp. 26-32, 2015.

[23] V. Matović, A. Buha, D. Đukić-Ćosić, and Z. Bulat, "Insight into the oxidative stress induced by lead and/or cadmium in blood, liver and kidneys," Food and Chemical Toxicology, vol. 78, pp. 130-140, 2015.

[24] A. Cherfi, S. Abdoun, and O. Gaci, "Food survey: levels and potential health risks of chromium, lead, zinc and copper content in fruits and vegetables consumed in Algeria," Food and Chemical Toxicology, vol. 70, pp. 48-53, 2014. 
[25] M. A. Rahman, M. M. Rahman, S. M. Reichman, R. P. Lim, and R. Naidu, "Heavy metals in Australian grown and imported rice and vegetables on sale in Australia: health hazard," Ecotoxicology and Environmental Safety, vol. 100, pp. 53-60, 2014.

[26] R. S. Moriarity, J. T. Harris, and R. D. Cox, "Lead toxicity as an etiology for abdominal pain in the emergency department," Journal of Emergency Medicine, vol. 46, no. 2, pp. e35-e38, 2014.

[27] M. Yeganeh, M. Afyuni, A.-H. Khoshgoftarmanesh et al., "Mapping of human health risks arising from soil nickel and mercury contamination," Journal of Hazardous Materials, vol. 244-245, pp. 225-239, 2013.

[28] K. K. Das, S. N. Das, and S. A. Dhundasi, "Nickel, its adverse health effects \& oxidative stress," Indian Journal of Medical Research, vol. 128, no. 4, pp. 412-425, 2008.

[29] J. Arvay, D. Bajcan, and J. Tomas, The Quality of Environmental Components in the Stiavnica River Alluvium, SUA in Nitra, 2012 (Slovak).

[30] M. Qu, W. Li, and C. Zhang, "Assessing the risk costs in delineating soil nickel contamination using sequential Gaussian simulation and transfer functions," Ecological Informatics, vol. 13, pp. 99-105, 2013.

[31] F. W. Sunderman Jr., "Biological monitoring of nickel in humans," Scandinavian Journal of Work, Environment and Health, vol. 19, no. 1, pp. 34-38, 1993.

[32] D. Schaumlöffel, "Nickel species: analysis and toxic effects," Journal of Trace Elements in Medicine and Biology, vol. 26, no. 1, pp. 1-6, 2012.

[33] A. Vollmannova, S. Zupka, D. Bajcan, M. Medvecky, and J. Daniel, "Dangerous heavy metals in soil and small forest fruit as a result of old environmental loads," in Proceedings of the 14th International Conference on Environmental Science and Technology, p. 528, Rhodes, Greece, 2015.

[34] J. Musilova, J. Bystricka, J. Lachman, L. Harangozo, P. Trebichalsky, and B. Volnova, "Potatoes-a crop resistant against input of heavy metals from the metallicaly contaminated soil," International Journal of Phytoremediation, vol. 18, no. 6, pp. 547552, 2015.

[35] J. Árvay, J. Tomáš, M. Hauptvogl et al., "Contamination of wildgrown edible mushrooms by heavy metals in a former mercurymining area," Journal of Environmental Science and Health, Part B, vol. 49, no. 11, pp. 815-827, 2014.

[36] B. Vokal, J. Cepl, E. Hausvater, and V. Rasocha, Grown Potatoes, Grada, Holešovice, Czech Republic, 2003.

[37] G. Du Laing, D. R. J. Vanthuyne, B. Vandecasteele, F. M. G. Tack, and M. G. Verloo, "Influence of hydrological regime on pore water metal concentrations in a contaminated sedimentderived soil," Environmental Pollution, vol. 147, no. 3, pp. 615625, 2007.

[38] F. Zeng, S. Ali, H. Zhang et al., "The influence of $\mathrm{pH}$ and organic matter content in paddy soil on heavy metal availability and their uptake by rice plants," Environmental Pollution, vol. 159, no. 1, pp. 84-91, 2011.

[39] A. Gebrekidan, Y. Weldegebriel, A. Hadera, and B. Van der Bruggen, "Toxicological assessment of heavy metals accumulated in vegetables and fruits grown in Ginfel river near Sheba Tannery, Tigray, Northern Ethiopia," Ecotoxicology and Environmental Safety, vol. 95, pp. 171-178, 2013.

[40] M. Hudec, Z. Jenisová, and J. Braniša, "Spectroscopic characteristics of humic substances in relation to lead and cadmium levels in contaminated soils from Western Carpathians," Carpathian Journal of Earth and Environmental Sciences, vol. 9, no. 4, pp. 47-54, 2014.
[41] L. Yang, B. Huang, W. Hu, Y. Chen, M. Mao, and L. Yao, “The impact of greenhouse vegetable farming duration and soil types on phytoavailability of heavy metals and their health risk in eastern China," Chemosphere, vol. 103, pp. 121-130, 2014.

[42] A. Vollmannova, L. Lahucky, J. Tomas, A. Hegedusova, and K. Jomov, "The arrangement of extremely acid soil reaction in relationship to $\mathrm{Cd}, \mathrm{Pb}, \mathrm{Cr}$ and $\mathrm{Ni}$ intake by the plants," Ekologia Bratislava, vol. 21, no. 4, pp. 442-448, 2002.

[43] A. McCauley, C. Jones, and J. Jacobsen, Soil pH and Organic Matter, MSU Extension, Bozeman, Mont, USA, 2009, (http:// landresources.montana.edu/nm/documents/NM8.pdf).

[44] N. S. Bolan, D. C. Adriano, P. Duraisamy, and A. Mani, "Immobilization and phytoavailability of cadmium in variable charge soils. III. Effect of biosolid compost addition," Plant and Soil, vol. 256, no. 1, pp. 231-241, 2003.

[45] J. H. Park, D. Lamb, P. Paneerselvam, G. Choppala, N. Bolan, and J.-W. Chung, "Role of organic amendments on enhanced bioremediation of heavy metal(loid) contaminated soils," Journal of Hazardous Materials, vol. 185, no. 2-3, pp. 549-574, 2011.

[46] K. Khan, Y. Lu, H. Khan et al., "Heavy metals in agricultural soils and crops and their health risks in Swat District, northern Pakistan," Food and Chemical Toxicology, vol. 58, pp. 449-458, 2013.

[47] A. Liénard, Y. Brostaux, and G. Colinet, "Soil contamination near a former $\mathrm{Zn}-\mathrm{Pb}$ ore-treatment plant: evaluation of deterministic factors and spatial structures at the landscape scale," Journal of Geochemical Exploration, vol. 147, pp. 107-116, 2014.

[48] P. Li, C. Lin, H. Cheng, X. Duan, and K. Lei, "Contamination and health risks of soil heavy metals around a lead/zinc smelter in southwestern China," Ecotoxicology and Environmental Safety, vol. 113, pp. 391-399, 2015.

[49] B. J. Alloway, Heavy Metal in Soil, Blackie and Son, Glasgow, Scotland, 1990.

[50] E. Merian, Metals and Their Coumpounds in the Environment. Occurencie, Analysis and Biological Relevance, VCH, Weinheim, Germany, 1991.

[51] M. Jamborova, Potato-Situation and Outlook Report for 30. 6, 2015 (Slovak), http://www.vuepp.sk/dokumenty/komodity/ 2015/zem12-15.pdf.

[52] EFSA, "Scientific opinion on lead in food. EFSA panel on contaminants in the food chain (CONTAM)," EFSA Journal, vol. 8 , no. 4, p. $1570,2010$.

[53] EFSA, "Statement on tolerable weekly intake for cadmium. EFSA Panel on Contaminants in the Food Chain (CONTAM)," The EFSA Journal, vol. 9, no. 2, pp. 1-19, 1975.

[54] EFSA, "Scientific Opinion on the risks to public health related to the presence of nickel in food and drinking water. EFSA Panel on Contaminants in the Food Chain (CONTAM)," EFSA Journal, vol. 13, no. 2, p. 4002, 2015.

[55] EFSA Scientific Committee, "Guidance on selected default values to be used by the EFSA Scientific Committee, Scientific Panels and Units in the absence of actual measured data," EFSA Journal, vol. 10, no. 3, p. 2579, 2012.

[56] Y.-T. Tang, T.-H. B. Deng, Q.-H. Wu et al., "Designing cropping systems for metal-contaminated sites: a review," Pedosphere, vol. 22, no. 4, pp. 470-488, 2012.

[57] J. Musilova, D. Jonasova, and Z. Polakova, "Variety as one of the factors affecting the accumulation of risk elements of potato tubers," Environment and Natural Resources, vol. 48, no. 3, pp. 131-142, 2011. 
[58] J. Musilova, D. Hrabovska, B. Volnova, and Z. Polakova, "Does consumption of potatoes cultivated in soils contaminated by heavy metals poses any risk to human health?" Environmental Protection and Natural Resources, vol. 24, no. 2, pp. 25-28, 2013.

[59] J. R. Miller, K. A. Hudson-Edwards, P. J. Lechler, D. Preston, and M. G. Macklin, "Heavy metal contamination of water, soil and produce within riverine communities of the Río Pilcomayo basin, Bolivia," Science of the Total Environment, vol. 320, no. 2-3, pp. 189-209, 2004.

[60] S. A. Mansour, M. H. Belal, A. A. K. Abou-Arab, H. M. Ashour, and M. F. Gad, "Evaluation of some pollutant levels in conventionally and organically farmed potato tubers and their risks to human health," Food and Chemical Toxicology, vol. 47, no. 3, pp. 615-624, 2009.

[61] Q.-W. Yang, Y. Xu, S.-J. Liu, J.-F. He, and F.-Y. Long, "Concentration and potential health risk of heavy metals in market vegetables in Chongqing, China," Ecotoxicology and Environmental Safety, vol. 74, no. 6, pp. 1664-1669, 2011.

[62] M. H. H. Ali and K. M. Al-Qahtani, "Assessment of some heavy metals in vegetables, cereals and fruits in Saudi Arabian markets," Egyptian Journal of Aquatic Research, vol. 38, no. 1, pp. 31-37, 2012. 

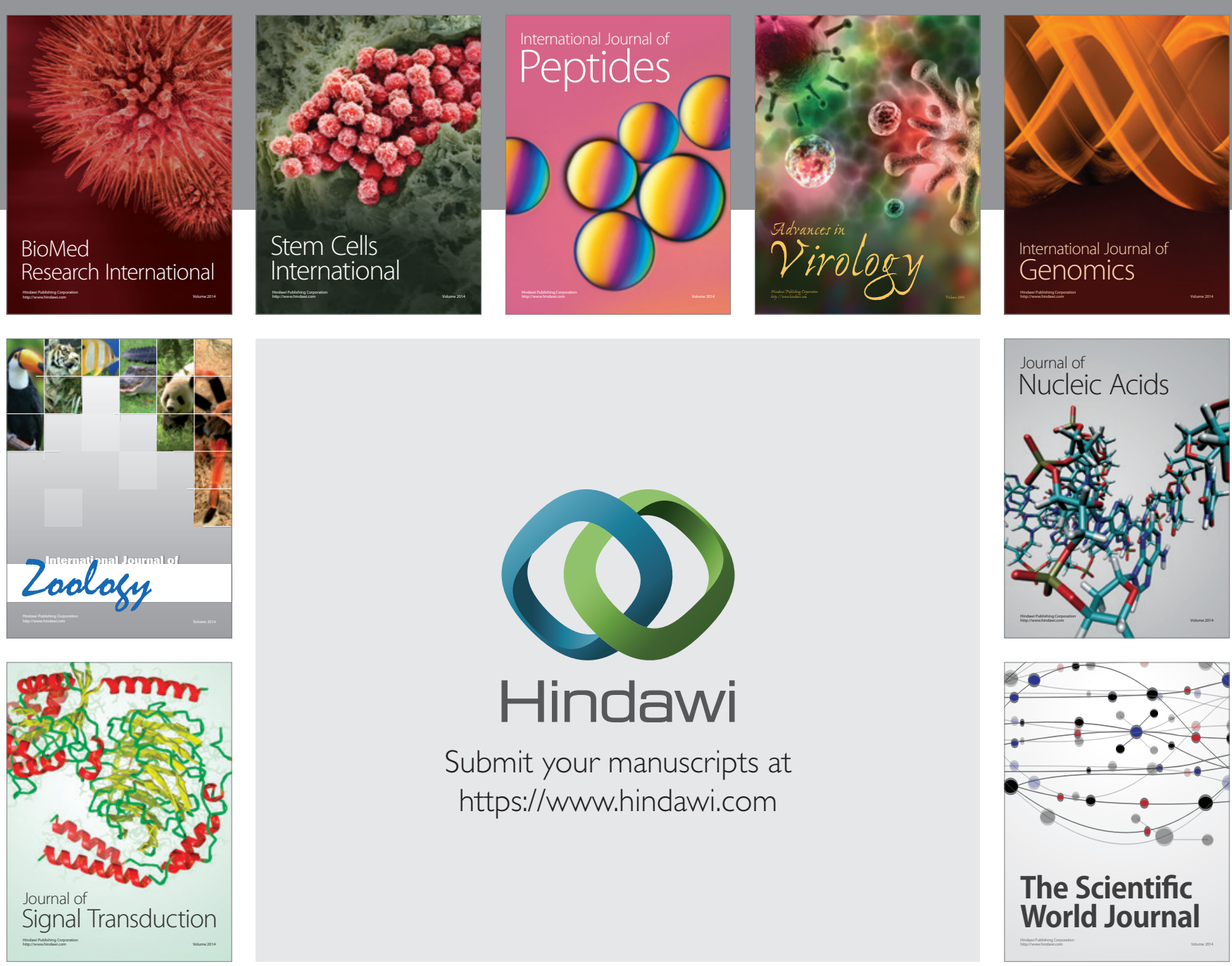

Submit your manuscripts at

https://www.hindawi.com
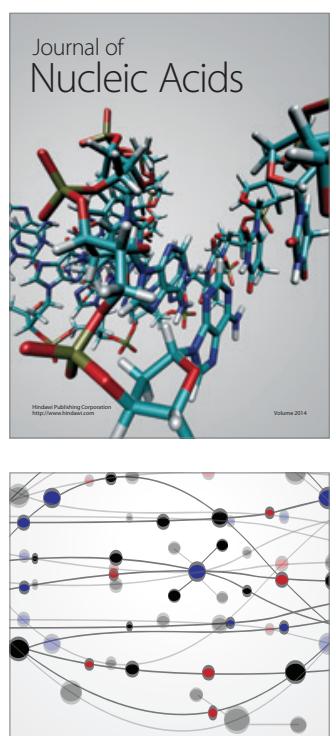

The Scientific World Journal
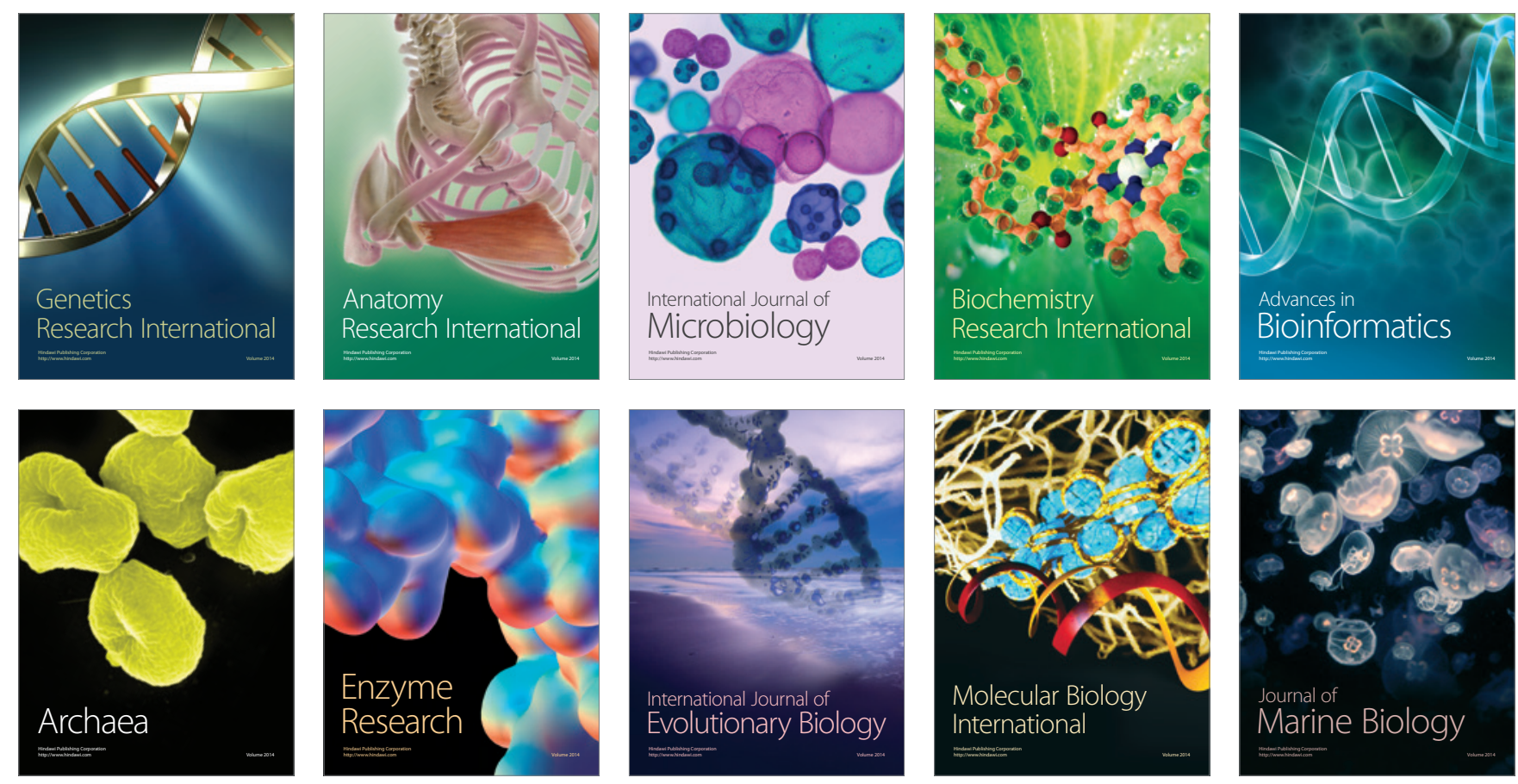